\title{
Basketball, AIDS and education
}

The very public announcement of the HIV infection of a famous basketball player in the United States should shame the US government into public education.

\section{New York}

TRAGIC though the circumstances are, the announcement last week that 'Magic' Johnson, the outstanding member of the Los Angeles Lakers basketball team, is infected with human immunodeficiency virus (HIV) may yet be the most effective means of getting rid of the confusion that now attends public understanding of this awful and awesome disease. For Johnson has courageously taken the initiative in talking about the predicament in which he finds himself, and has let it be known that his infection stems from heterosexual intercourse. His announcement that he was retiring from basketball because of the HIV infection, delivered in a press conference on 7 November, made headlines across the United States; he subsequently appeared on a popular late-night talk show to discuss his predicament. Johnson's wife of eight weeks, who is newly pregnant, is so far free from HIV, but these are only early days.

Outside the United States, the full drama of these events can hardly be appreciated. Johnson is a hero on the scale of Hercules. In more than a decade on the boards, he has personally made basketball into a fastmoving strategic business, not just an opportunity for competing athletes to show themselves more skillful than their teammates at lobbing a ball into a narrow pipe of netting.

There is more to it than that. Johnson is particularly a hero of the black ghettos, in Los Angeles especially (remember Watts?). Last year, he is reckoned to have earned \$5 million, thus keeping alive the American dream that the poorest kids from the backstreets can also make it if only they are sharp and willing to work. To learn that Johnson has been infected with HIV is a great shock.

How did such a calamity come about? That is what the hero-worshippers ask. Can Johnson be homosexual? He has told them he is not; because he is such a hero, he will be believed without question. And so the truth is now sinking in throughout the United States that AIDS can be transmitted in heterosexual intercourse. $\mathrm{Al}$ though African experience and the trend of new cases elsewhere has made that clear since 1985 or thereabouts, there remains a stolid subpopulation unwilling to believe. Now, even they are likely to take in the message.

This is an opportunity that the US government should not ignore. Over the past few years, the first flush of enthusiasm for public education on AIDS has largely evaporated. There is counselling for some of those found to be infected, or to have developed overt AIDS, while the notion of 'safe sex' (which means the use of condoms) is at least widely understood (as is the risk of using drugs intravenously). But voluntary groups are more active than the government, now as always fearful of losing the prurience vote. Johnson's plight seems to have startled the whole United States. Should it not also shame the government into action of a much more energetic kind?

But what can be said that is new, or will carry weight with those at risk of contracting AIDS? Nothing really. But in the United States, where almost everybody knows of somebody who has fallen ill with AIDS, or even died, and where there are many other things to worry people (jobs, for example), it is only natural that the appearance of AIDS in others sometimes seems a proof to many people that it will never happen to them. The novelty is Magic Johnson; if people, especially those most at risk, see that even their heroes can be struck down, it may be easier to bridge that gap in logic. That Johnson wants to help get the message across makes the opportunity more compelling.

The US government has not yet played a significant part in public education on AIDS - a responsibility faced directly by most European and many other governments. Of course, the government encourages voluntary agencies with an inclination to take on this work, while agencies such as the Centers for Disease Control and the National Institutes of Health are even more supportive. But these efforts, however imaginative and well intentioned, cannot compare with a well-run government campaign. The snag is that, as things are, there would be no choice but to plead for a condom culture. There is really no alternative. Vice-President Dan Quayle's statement at the weekend that Johnson's case shows that chastity is the only safe way of avoiding AIDS is correct enough, but suggests that the government is hanging back in the hope that the world will be transformed into a different world, perhaps an ideal one.

What needs to be said (and the need to say it) is entirely unaffected by the continuing uncertainties over the mechanism of the disease. There is no dispute that AIDS is triggered by HIV infection; the uncertainties arise over what happens then - the pathogenesis of AIDS.

An article in this space a few weeks ago (Nature 353, 297; 26 September 1991) showed vividly what passions even that esoteric issue can stir up. The argument, some may recall, was that some data gathered in chimpanzees by a British group and in mice by a Canadian group in British Columbia appeared to be consistent with a view put forward by Geoffrey W. Hoffmann (one of the Canadian group) that the destruction of T cells in AIDS (and pre-AIDS) is caused not by the spread of HIV itself but by an autoimmune reaction between $\mathrm{T}$ cells made possible by the similarity of the structure of one of the coat proteins and part of an MHC molecule on the T-cell surface. Unwisely, as it seems in retrospect, the article also mentioned approvingly Professor Peter Duesberg from the University of California at Berkeley, noting that he has consistently argued that more attention should be paid to the curious circumstance that only a small proportion of $\mathrm{T}$ cells are found to carry HIV.

The mere mention of Duesberg's name seems to have stimulated both vitriol and misunderstanding. Two other weekly journals, Science and New Scientist, reported that the article held that Duesberg had been "correct" and that others working in the field disagreed. Duesberg has sometimes argued that HIV is not even a necessary condition for AIDS, but what Nature's article said was simply that Duesberg should sleep more easily at night because there is a theory, and some data to support it, to explain the unusual properties of the infected state. Duesberg has made a nuisance of himself, it is true, but does that mean that everything he says and does is wrong?

Otherwise, there have been about a dozen letters (some of which will be published soon) and three offers of more formal papers supporting the Hoffmann view. It will be interesting to see how that comes out.

It might even help Magic Johnson. What would be described, for an ordinary virus, as the incubation period, remains very long. Yet despite efforts everywhere, progress towards a cure is slow, to say the least. Meanwhile, it may be cold comfort for Johnson that his case should make such an important contribution to public education.

John Maddox 